\title{
Pengaruh Kompensasi Terhadap Kinerja Karyawan Koperasi
}

\author{
Burhanudin $^{1)}$, Iyan Tri Suryanto ${ }^{2)}$ \\ Fakultas Ekonomi dan Bisnis Universitas Janabadra Yogyakarta ${ }^{1)}{ }^{2)}$ \\ burhanudin@janabadra.ac.id ${ }^{1)}$, ian.scecter@gmail.com ${ }^{2)}$
}

\begin{abstract}
ABSTRAK
Penelitian ini bertujuan untuk mengetahui pengaruh kompensasi finansial dan kompensasi nonfinansial terhadap kinerja karyawan. Subjek dalam penelitian ini adalah 60 orang karyawan Koperasi Simpan Pinjam Credit Union Dharma Kita di Sleman, Yogyakarta. Teknik pengumpulan data menggunakan kuesioner, sedangkan alat analisis menggunakan regresi linear berganda. Hasil penelitian menunjukkan bahwa kompensasi finansial tidak berpengaruh terhadap kinerja karyawan Koperasi Simpan Pinjam Credit Union Dharma Kita di Sleman, sedangkan kompensasi nonfinansial berpengaruh terhadap kinerja karyawan Koperasi Simpan Pinjam Credit Union Dharma Kita di Sleman.
\end{abstract}

Kata kunci: kompensasi finansial, kompensasi nonfinansial, kinerja karyawan.

\begin{abstract}
The present study aimed to find out the effect of financial and non-financial compensation on employees' performance. The participants of the study were sixty employees of Credit Union Dharma Kita Savings and Loans Cooperative, Sleman, Yogyakarta. The data were collected using questionnaire. Multiple linear regression was applied to analyze the data. The result of the study showed that financial compensation did not affect the Credit Union Dharma Kita Savings and Loans Cooperative employees' performance, whereas non-financial compensation was reported to affect the Credit Union Dharma Kita Savings and Loans Cooperative employees' performance.
\end{abstract}

Keywords: financial compensation, non-financial compensation, employee's performance

\section{PENDAHULUAN}

Dalam persaingan bisnis yang semakin ketat seperti sekarang ini, setiap perusahaan dituntut untuk dapat tetap survive dalam jangka Panjang. Salah satu cara agar perusahaan dapat bertahan dalam jangka Panjang adalah dengan mengelola kinerja karyawannya. Pengelolaan kinerja karyawan yang tepat, merupakan salah satu faktor yang memberi kontribusi pada pencapaian keunggulan kompetitif. Kinerja karyawan dapat diartikan sebagai hasil kerja baik secara kuantitas maupun kualitas yang dicapai oleh seorang karyawan (Mangkunegara, 2017).

Kinerja karyawan merupakan sinergi dari berbagai faktor. Secara garis besarnya, ada tiga faktor yang mempengaruhi kinerja karyawan yaitu faktor lingkungan internal, faktor lingkungan eksternal, dan faktor individu. Salah satu faktor lingkungan internal organisasi yang mempengaruhi kinerja karyawan adalah kompensasi (Wirawan, 2009). Kompensasi adalah total dari penghargaan yang diberikan kepada karyawan sebagai imbalan atas jasa mereka yang diberikan kepada organisasi atau perusahaan. Berdasarkan bentuknya, kompensasi dapat dibedakan menjadi dua jenis yaitu kompensasi finansial dan kompensasi nonfinansial. Kompensasi finansial dapat berupa gaji, upah komisi, bonus dan sebagainya. Sedangkan kompensasi nonfinansial merupakan kepuasan seorang karyawan yang diperoleh dari pekerjaan dan dari lingkungan kerjanya (Sinambela, 2016).

Kebijakan kompensasi hendaknya didisain untuk mencapai tiga tujuan utama yaitu meningkatkan kinerja, meningkatkan daya saing, dan keadilan. Kompensasi seharusnya tidak dianggap sebagai biaya bagi perusahaan, akan tetapi dijadikan sebagai sarana untuk meraih keunggulan kompetitif dan alat untuk menyelaraskan aset perusahaan yang unik yaitu karyawan dengan strategi perusahaan (Armstrong \& Taylor, 2014). Kebijakan kompensasi hendaknya dapat mempengaruhi karyawan untuk mencapai kinerja yang optimal yang pada gilirannya dapat membantu pencapaian tujuan perusahaan.

Bagi karyawan, kompensasi memiliki beberapa fungsi. Kompensasi memiliki fungsi untuk menjamin kehidupan yang layak bagi karyawan dan keluarganya. Artinya dengan kompensasi, maka 
karyawan tersebut dapat memenuhi kebutuhan hidupnya dan keluarganya. Kompensasi juga mencerminkan imbalan atas jasa seorang karyawan terhadap perusahaan. Besar kecilnya kompensasi menggambarkan tingkat kontribusi karyawan pada perusahaan, dan menggambarkan besar kecilnya tanggungjawab tugas atau pekerjaan yang diemban karyawan.

Fungsi lain dari kompensasi adalah untuk memotivasi karyawan dalam meningkatkan kinerjanya. Kebijakan kompensasi yang tepat dapat meningkatkan kepuasan, yang selanjutnya akan memotivasi karyawan untuk bekerja lebih baik (Yuniarsih \& Suwatno, 2016). Untuk menguji pengaruh kompensasi terhadap kinerja karyawan, maka penelitian ini bertujuan mengetahui pengaruh kompensasi finansial dan nonfinansial terhadap kinerja karyawan. Adapun subjek dalam penelitian ini adalah karyawan Koperasi Simpan Pinjam (KSP) Credit Union Dharma Kita yang berlokasi di kecamatan Mlati, kabupaten Sleman, Daerah Istimewa Yogyakarta.

\section{TINJAUAN PUSTAKA}

\section{Pengertian Kinerja}

Kinerja (job performance) adalah hasil kerja yang dilakukan oleh seorang karyawan baik secara kualitas maupun kuantitas sesuai dengan tanggungjawabnya. Kualitas kerja antara lain mencakup ketelitian, kebersihan, sedangkan kuantitas kerja antara lain output yang dihasilkan (Mangkunegara, 2017).

Kinerja sebenarnya memiliki makna yang lebih luas tidak hanya hasil kerja, tetapi juga termasuk bagaimana proses pekerjaan berlangsung. Kinerja berkaitan dengan proses melaksanakan pekerjaan dan hasil yang dicapai dari pekerjaan tersebut. Kinerja adalah mengenai apa yang dikerjakan dan bagaimana cara mengerjakannya (Wibowo, 2016).

\section{Faktor-faktor yang Mempengaruhi Kinerja Karyawan}

Kinerja karyawan merupakan hasil sinergi dari sejumlah faktor. Adapun faktor-faktor yang mempengaruhi kinerja karyawan terdiri dari faktor lingkungan eksternal, faktor lingkungan internal, dan faktor internal karyawan. Faktor lingkungan eksternal organisasi adalah keadaan, kejadian, atau situasi yang terjadi di lingkungan eksternal organisasi yang dapat mempengaruhi kinerja karyawan. Faktor-faktor eksternal antara lain kondisi ekonomi, politik, sosial, budaya dan agama masyarakat, serta kompetitor.

Faktor lingkungan internal organisasi merupakan dukungan yang diberikan oleh organisasi kepada karyawan dalam rangka pelaksanaan pekerjaan. Dukungan tersebut dapat mempengaruhi tinggi rendahnya kinerja seorang karyawan. Faktor-faktor lingkungan internal ini antara lain visi dan misi organisasi, strategi organisasi, sistem manajemen, teknologi, gaya kepemimpinan, budaya organisasi, rekan sekerja, dan kompensasi.

Sementara itu faktor internal karyawan adalah faktorfaktor yang ada dalam diri karyawan, yang merupakan faktor bawaan sejak lahir dan faktor yang diperoleh selama perkembangan hidupnya. Faktorfaktor bawaan misalnya bakat dan sifat pribadi, keadaan fisik dan kejiwaan. Sedangkan faktor-faktor yang diperoleh misalnya pengetahuan, keterampilan, kompetensi, pengalaman kerja, dan motivasi kerja (Wirawan, 2009).

\section{Pengertian dan Jenis-jenis Kompensasi}

Kompensasi adalah total dari penghargaan yang diberikan kepada karyawan sebagai imbalan atas jasa mereka yang diberikan kepada organisasi. Adapun jenis-jenis kompensasi dapat dibedakan menjadi dua kategori yaitu kompensasi berdasarkan bentuknya dan berdasarkan cara pemberiannya.

Berdasarkan bentuknya, kompensasi dapat dibedakan menjadi dua jenis yaitu kompensasi finansial dan kompensasi nonfinansial. Kompensasi finansial dapat berupa gaji, upah, komisi, bonus dan sebagainya. Sedangkan kompensasi nonfinansial merupakan kepuasan seorang karyawan yang diperoleh dari pekerjaan dan dari lingkungan kerjanya. Kompensasi nonfinansial yang berasal dari pekerjaan antara lain pengakuan, tantangan, tanggungjawab, tugas-tugas yang menarik, dan rasa pencapaian. Kompensasi nonfinansial yang berasal dari lingkungan kerja meliputi kebijakan yang sehat, lingkungan kerja yang nyaman, rekan kerja yang menyenangkan, supervisor yang kompeten dan sebagainya.

Berdasarkan cara pemberiannya, kompensasi dapat dibedakan menjadi dua yaitu kompensasi finansial langsung dan kompensasi finansial tidak langsung. Kompensasi finansial langsung mencakup gaji, upah, bonus, komisi dan sebagainya. Sedangkan kompensasi finansial tidak langsung berupa tunjangan-tunjangan seperti tunjangan asuransi tenaga kerja, asuransi kesehatan, cuti, dan sebagainya (Sinambela, 2016).

\section{Tujuan Pemberian Kompensasi}

Kompensasi memiliki beberapa tujuan. Tujuan pemberian kompensasi antara lain adalah (Sinambela, 2016): 
1. Untuk menarik karyawan yang berkualifikasi. Pemberian kompensasi yang tinggi dan kompetitif diharapkan dapat menarik kandidatkandidat yang memenuhi kualifikasi agar bergabung ke dalam organisasi.

2. Untuk mempertahankan karyawan yang berkualitas. Kebijakan kompensasi bertujuan untuk mempertahankan agar orang-orang yang berkualitas tetap tinggal atau bersedia bekerja untuk organisasi.

3. Menjamin keadilan. Tujuan pemberian kompensasi antara lain untuk mewujudkan persepsi keadilan di antara para karyawan, baik keadilan internal maupun keadilan eksternal.

4. Menghargai perilaku yang diinginkan. Pemberian kompensasi bertujuan untuk memberikan penghargaan terhadap perilaku yang diinginkan di tempat kerja misalnya pemberian insentif atas kinerja.

5. Mengendalikan biaya. Sistem kompensasi yang efektif, membantu organisasi untuk memperoleh dan mempertahankan karyawan dengan biaya yang rasional.

6. Memenuhi peraturan hukum. Pemberian kompensasi juga bertujuan untuk mematuhi peraturan pemerintah di bidang ketenakerjaan, misahnya peraturan upah minimum.

7. Memfasilitas pengertian. Sistem kompensasi hendaknya dapat dipahami oleh semua anggota atau bagian dalam organisasi, seperti para karyawan, bagian personalia atau SDM, bagian pemasaran dan sebagainya.

8. Meningkatkan efisiensi administrasi. Pemberian kompensasi hendaknya dirancang sedemikian rupa, sehingga dapat meningkatkan efisiensi administrasi organisasi.

\section{Faktor-faktor yang Mempengaruhi Kompensasi}

Secara garis besar, ada dua faktor yang mempengaruhi kebijakan kompensasi yaitu faktor internal dan faktor eksternal. Faktor internal terdiri dari daur hidup organisasi, budaya organisasi, kesediaan untuk membayar, dan kemampuan organisasi untuk membayar kompensasi.

1) Daur hidup organisasi. Kebijakan kompensasi dipengaruhi oleh daur hidup organisasi. Masingmasing tahap yang terdiri dari tahap permulaan, pertumbuhan, kedewasaan, dan penurunan, dapat mempengaruhi kebijakan kompensasi.
2) Budaya organisasi. Setiap organisasi memiliki budaya yang berbeda-beda, sehingga kebijakan kompensasi merepresentasikan nilai-nilai budaya yang mereka anut.

3) Kesediaan untuk membayar. Kalau boleh berpikir positif sebenarnya organisasi ingin memberikan kompensasi kepada karyawannya secara adil dan layak. Untuk merealisasi niat tersebut, maka organisasi perlu mendorong karyawannya untuk meningkatkan kinerjanya, dan karyawan juga meningkatkan produktivitasnya.

4) Kemampuan untuk membayar. Organisasi memiliki kemampuan yang berbeda-beda dalam memberikan kompensasi kepada karyawannya. Sebagai contoh ada organisasi yang mampu memberikan upah atau gaji sesuai dengan peraturan upah minimum, sebaliknya ada pula organisasi yang belum mampu memberikan upah atau gaji sesuai peraturan upah minimum.

Adapun faktor-faktor eksternal yang mempengaruhi kebijakan kompensasi meliputi pasar tenaga kerja, peraturan pemerintah, dan serikat pekerja.

a. Pasar tenaga kerja. Penawaran dan permintaan tenaga kerja akan menentukan kebijakan kompensasi. Jika suplai tenaga kerja rendah, ada kecenderungan organisasi akan memberikan kompensasi yang tinggi. Sebaliknya jika suplai tenaga kerja melimpah, ada kecenderungan organisasi akan memberikan kompensasi yang wajar atau rendah.

b. Peraturan pemerintah. Peraturan pemerintah khususnya yang berkaitan dengan pengupahan, akan mengikat organisasi untuk mematuhinya. Oleh sebab itu kebijakan kompensasi juga akan mengacu pada peraturan tersebut.

c. Organisasi serikat pekerja. Kebijakan kompensasi di organisasi yang memiliki serikat pekerja dengan yang tidak memiliki serikat pekerja cenderung berbeda. Serikat pekerja seringkali memiliki kekuatan agar organisasi memberikan upah atau gaji sesuai dengan tuntutan mereka (Al Fajar \& Heru, 2013).

\section{Pengaruh Kompensasi Finansial Terhadap Kinerja Karyawan}

Salah satu faktor internal yang mempengaruhi kinerja karyawan adalah kompensasi. Berdasarkan bentuknya, kompensasi dapat dibedakan menjadi dua jenis yaitu kompensasi finansial dan kompensasi nonfinansial. Hasil penelitian Arief et al. (2016) menemukan bahwa kompensasi finansial berpengaruh secara signifikan terhadap kinerja karyawan. Ukuran 
sampel dalam Penelitian ini adalah 72 orang yaitu karyawan bagian instalasi PTPN XI (persero) PG. Pradjekan Bondowoso.

Hasil penelitian Hadi (2014) dengan sampel 56 orang karyawan, yaitu 40 karyawan tetap dan 16 karyawan kontrak PT. Bank Rakyat Indonesia (Persero) Tbk. Cabang Teluk Kuantan, menemukan bahwa kompensasi finansial berpengaruh positif dan signifikan terhadap kinerja karyawan. Penelitian Hamdan \& Setiawan (2014) dengan sampel 80 karyawan PT. Samudera Buana Persada Surabaya, menemukan bahwa kompensasi finansial berpengaruh secara signifikan terhadap kinerja karyawan.

Hasil penelitian Handayani (2017) menemukan bahwa kompensasi finansial berpengaruh secara positf dan signifikan terhadap kinerja karyawan. Penelitian ini mengambil sampel 92 orang pegawai harian lepas di Dinas Lingkungan Hidup dan Kebersihan kota Palembang. Penelitian Hinaya \& Suryati (2019) dengan sampel 35 karyawan Kantor Badan Penanggulangan Bencana Daerah (BPBD) Kota Palopo, juga menemukan bahwa kompensasi finansial berpengaruh secara signifikan terhadap kinerja karyawan. Selanjutnya penelitian Ismantara \& Pranatasari (2019) dengan sampel 83 orang karyawan SPBU BS Group, menemukan bahwa kompensasi finansial berpengaruh secara signifikan terhadap kinerja karyawan.

Hasil penelitian Irawan et al. (2014) menemukan bahwa kompensasi finansial berpengaruh secara signifikan terhadap kinerja karyawan. Sampel dalam penelitian ini adalah seluruh agen AJB Bumiputera 1912 kantor cabang Blitar yang berjumlah 68 orang. Hasil penelitian Leonardo \& Andreani (2015) menemukan bahwa kompensasi finansial berpengaruh positif dan signifikan terhadap kinerja karyawan. Penelitian ini dilakukan pada PT. Kopanitia, dengan ukuran sampel 50 orang karyawan.

Penelitian yang dilakukan oleh Priyatono (2019), dengan ukuran sampel 50 orang karyawan pada Mesastila Hotels \& Resort Magelang, menemukan bahwa kompensasi finansial berpengaruh signifikan terhadap kinerja karyawan. Hasil penelitian Suci \& Syamsir (2018) dengan ukuran sampel 38 orang, menemukan bahwa kompensasi finansial memiliki pengaruh yang signifikan terhadap kinerja perangkat Nagari dalam pengelolaan keuangan Nagari di Kecamatan Salimpaung. Penelitian ini dilakukan di enam kantor Walinagari yang berada di kecamatan Salimpaung, Kabupaten Tanah Datar.

Hasil penelitian Suseno et al. (2014) dengan sampel 62 karyawan Bank BRI Cabang Jember, menemukan bahwa kompensasi finansial memiliki pengaruh signifikan terhadap kinerja karyawan bank BRI Cabang Jember. Penelitian yang dilakukan oleh Syafi'ah et al. (2018) menemukan bahwa kompensasi finansial berpengaruh secara signifikan terhadap prestasi kerja karyawan. Ukuran sampel dalam penelitian ini adalah 104 karyawan PT. Polowijo Gosari Gresik. Adapun hipotesis yang diajukan dalam penelitian ini adalah:

Hipotesis ke 1: kompensasi finansial berpengaruh terhadap kinerja karyawan Koperasi Simpan Pinjam (KSP) Credit Union Dharma Kita Sleman.

\section{Pengaruh Kompensasi Nonfinansial Terhadap Kinerja Karyawan}

Hasil penelitian Hadi (2014) menemukan bahwa kompensasi nonfinansial berpengaruh positif dan signifikan terhadap kinerja karyawan. Penelitian ini dilakukan pada karyawan PT. Bank Rakyat Indonesia (Persero) Tbk. Cabang Teluk Kuantan, baik karyawan tetap maupun karyawan kontrak yang berjumlah 56 orang. Penelitian Hamdan \& Setiawan (2014) dengan sampel 80 karyawan PT. Samudera Buana Persada Surabaya, menemukan bahwa kompensasi nonfinansial berpengaruh secara signifikan terhadap kinerja karyawan.

Hasil penelitian Hinaya \& Suryati (2019) dengan ukuran sampel 35 orang pegawai kantor BPBD Palopo, menemukan bahwa kompensasi nonfinansial berpengaruh signifikan terhadap kinerja pegawai. Selanjutnya penelitian Ismantara \& Pranatasari (2019) dengan sampel 83 orang karyawan SPBU BS Group, menemukan bahwa kompensasi nonfinansial berpengaruh secara signifikan terhadap kinerja karyawan.

Hasil penelitian Leonardo \& Andreani (2015) menemukan bahwa kompensasi nonfinansial berpengaruh positif dan signifikan terhadap kinerja karyawan. Penelitian ini dilakukan pada PT. Kopanitia, dengan ukuran sampel 50 orang karyawan. Penelitian yang dilakukan oleh Priyatono (2019), dengan ukuran sampel 50 orang karyawan pada Mesastila Hotels \& Resort Magelang, menemukan bahwa kompensasi nonfinansial berpengaruh signifikan terhadap kinerja karyawan.

Hasil penelitian Suseno et al. (2014) dengan sampel 62 karyawan Bank BRI Cabang Jember, menemukan bahwa kompensasi nonfinansial memiliki pengaruh signifikan terhadap kinerja karyawan bank BRI Cabang Jember. Penelitian yang dilakukan oleh Syafi'ah et al. (2018) menemukan bahwa kompensasi nonfinansial berpengaruh secara signifikan terhadap prestasi kerja karyawan. Ukuran sampel dalam 
penelitian ini adalah 104 karyawan PT. Polowijo Gosari Gresik. Adapun hipotesis yang diajukan dalam penelitian ini adalah:

Hipotesis ke 2: kompensasi nonfinansial berpengaruh terhadap kinerja karyawan Koperasi Simpan Pinjam (KSP) Credit Union Dharma Kita Sleman.

\section{METODE PENELITIAN}

\section{Jenis Penelitian}

Penelitian ini merupakan penelitian kuantitatif yang merupakan metode untuk menguji teori-teori tertentu, secara deduktif, dengan cara meneliti hubungan antar variabel (Creswell, 2014). Variabel yang akan diuji dalam penelitian ini terdiri dari dua variabel independen yaitu kompensasi finansial dan kompensasi nonfinansial, dan satu variabel dependen yaitu kinerja karyawan.

\section{Populasi}

Populasi adalah keseluruhan subjek penelitian (Arikunto, 2010). Populasi dalam penelitian ini adalah seluruh karyawan Koperasi Simpan Pinjam (KSP) Credit Union Dharma Kita yang berlokasi di kecamatan Mlati, kabupaten Sleman, Daerah Istimewa Yogyakarta, yang berjumlah 60 orang. Oleh sebab itu penelitian ini merupakan penelitian populasi atau studi sensus.

\section{Definisi Operasional dan Pengukuran Variabel}

Kompensasi finansial (X1) adalah kompensasi yang diterima oleh karyawan dalam bentuk uang. Kompensasi finansial diukur dengan tiga indikator yaitu gaji, bonus, dan tunjangan kesehatan (Sinambela, 2016). Respon diukur menggunakan skala Likert yaitu 1 (sangat tidak setuju), 2 (tidak setuju), 3 (netral), 4 (setuju), dan 5 (sangat setuju).

Kompensasi nonfinansial (X2) adalah kompensasi yang diterima oleh karyawan dalam bentuk selain uang. Kompensasi nonfinansial diukur dengan enam indikator yaitu variasi tugas, tantangan tugas, tanggungjawab, lingkungan kerja yang nyaman, pengakuan, dan promosi (Sinambela, 2016). Respon diukur menggunakan skala Likert yaitu 1 (sangat tidak setuju), 2 (tidak setuju), 3 (netral), 4 (setuju), dan 5 (sangat setuju).

Kinerja karyawan (Y) adalah hasil kerja yang dicapai oleh seorang karyawan baik secara kualitas maupun kuantitas sesuai dengan tugas dan tanggungjawabnya (Mangkunegara, 2017). Kinerja karyawan diukur dengan enam indikator yaitu target, ketepatan waktu, kebersihan tempat kerja, kesalahan kerja, ketelitian, dan datang-pulang sesuai jam kerja. Respon diukur menggunakan skala Likert yaitu 1 (sangat tidak setuju), 2 (tidak setuju), 3 (netral), 4 (setuju), dan 5 (sangat setuju). Teknik pengumpulan data dalam penelitian ini menggunakan kuesioner. Pertanyaan dalam kuesioner bersifat tertutup dan diberikan secara langsung kepada responden yaitu karyawan koperasi KSP Credit Union Dharma Kita Sleman, Yogyakarta.

\section{Uji Validitas dan Reliabilitas}

Uji validitas dan reliabilitas dilakukan terhadap 35 responden. Uji validitas digunakan untuk mengukur valid atau tidaknya suatu kuesioner. Uji validitas dalam penelitian ini menggunakan Person correlation. Kriteria uji validitas yang digunakan dalam penelitian ini menggunakan taraf signifikansi 0,05 , artinya jika taraf signifikansi yang dihasilan oleh koefisien korelasi $\leq 0,05$, maka butir atau item yang bersangkutan dinyatakan valid (Mustafa, 2013). Hasil uji validitas variabel kompensasi finansial, kompensasi nonfinansial, dan kinerja karyawan disajikan pada tabel berikut.

Tabel 1. Hasil Uji Validitas

\begin{tabular}{cccc}
\hline Variabel & $\begin{array}{c}\text { No. } \\
\text { Item }\end{array}$ & Signifikansi & Keterangan \\
\hline Kompensasi & X1.1 & 0,000 & Valid \\
finansial (X1) & X1.2 & 0,000 & Valid \\
& X1.3 & 0,000 & Valid \\
Kompensasi & X2.1 & 0,000 & Valid \\
nonfinansial & X2.2 & 0,001 & Valid \\
(X2) & X2.3 & 0,000 & Valid \\
& X2.4 & 0,000 & Valid \\
& X2.5 & 0,000 & Valid \\
Kinerja & X2.6 & 0,000 & Valid \\
karyawan (Y) & Y2 & 0,000 & Valid \\
& Y3 & 0,000 & Valid \\
& Y4 & 0,000 & Valid \\
& Y5 & 0,000 & Valid \\
& Y6 & 0,000 & Valid \\
\hline
\end{tabular}

Sumber: data diolah

Berdasarkan hasil uji validitas tersebut, ternyata semua item memiliki taraf signifikansi lebih kecil dari 0,05, sehingga item-item pada variabel yang digunakan dalam penelitian ini dinyatakan valid.

Uji selanjutnya adalah uji reliabilitas. Uji reliabilitas dalam penelitian ini menggunakan alpha Cronbach. Kriteria yang digunakan adalah jika nilai Alpha Cronbach lebih dari 0,70, maka variabel tersebut dinyatakan reliabel. Hasil uji reliabilitas disajikan dalam tabel berikut. 
Tabel 2. Hasil Uji Reliabilitas

\begin{tabular}{cccc}
\hline No. & Variabel & $\begin{array}{c}\text { Alpha } \\
\text { Cronbach's }\end{array}$ & Keterangan \\
\hline 1 & $\begin{array}{c}\text { Kompensasi } \\
\text { finansial (X1) } \\
\text { Kompensasi } \\
\text { nonfinansial } \\
\text { (X2) }\end{array}$ & 0,799 & Reliabel \\
3 & $\begin{array}{c}\text { Kinerja } \\
\text { karyawan (Y) }\end{array}$ & 0,762 & Reliabel \\
& 0,768 & Reliabel \\
\hline
\end{tabular}

Sumber: data diolah

Berdasarkan hasil uji reliabilitas, ternyata semua variabel atau konstruk memiliki nilai alpha Cronbach lebih dari 0,70. Oleh sebab itu semua variabel yang digunakan dalam penelitian ini dinyatakan reliabel.

\section{HASIL DAN PEMBAHASAN}

\section{Karakteristik Responden}

Responden dalam penelitian ini berjumlah 60 orang. Karakteristik responden dalam penelitian ini dikategorikan berdasakan jenis kelamin, usia, pendidikan terakhir, dan masa kerja. Karakteristik responden disajikan pada tabel berikut.

Tabel 3. Karakteristik Responden

\begin{tabular}{cccc}
\hline $\begin{array}{c}\text { Karakteristik } \\
\text { Responden }\end{array}$ & Kategori & Jumlah & Persentase \\
\hline Jenis kelamin & Laki-laki & 33 & $55 \%$ \\
& Perempuan & 27 & $45 \%$ \\
Usia & $18-23$ & 4 & $6,67 \%$ \\
& $24-29$ & 32 & $53,3 \%$ \\
& Di atas 30 & 24 & $40 \%$ \\
tahun & & \\
Pendidikan & SMP & 1 & $1,67 \%$ \\
terakhir & SMA/SMK & 33 & $55 \%$ \\
& Diploma & 4 & $6,66 \%$ \\
& (D3) & & \\
Masa kerja & Sarjana (S1) & 22 & $36,67 \%$ \\
& Kurang dari & 5 & $8,3 \%$ \\
& 1 tahun & & \\
& $1-5$ tahun & 38 & $63,3 \%$ \\
& Lebih dari 6 & 17 & $28,3 \%$ \\
tahun & & \\
Total & & 60 & $100 \%$ \\
\hline
\end{tabular}

Sumber: data diolah

Berdasarkan jenis kelamin, maka responden laki-laki berjumlah 33 orang dan perempuan 27 orang. Karakteristik responden berdasarkan usia, usia 18 sampai 23 tahun ada 4 orang, usia 24 sampai 29 tahun ada 32 orang, dan usia di atas 30 tahun ada 24 orang. Berdasarkan tingkat pendidikannya, responden dengan pendidikan terakhir SMP ada 1 orang, pendidikan terakhir SMA/SMK ada 33 orang, pendidikan terakhir diploma (D3) ada 4 orang, dan responden dengan pendidikan terakhir sarjana (S1) ada 22 orang. Sementara itu berdasarkan masa kerja, responden dengan masa kerja kurang dari 1 tahun ada 5 orang, responden dengan masa kerja antara 1 sampai dengan 5 tahun ada 38 orang, dan responden dengan masa kerja lebih dari 6 tahun ada 17 orang.

\section{Statistik Deskriptif}

Statistik deskriptif dalam penelitian ini memberikan gambaran atau deskripsi data mengenai kompensasi finansial, kompensasi nonfinansial, dan kinerja karyawan, yang terdiri dari nilai minimum, maksimum, nilai rata-rata, dan standar deviasi. Hasil analisis statistik deskriptif dapat dilihat pada tabel berikut.

Tabel 4. Statistik Deskriptif

\begin{tabular}{|c|c|c|c|c|c|}
\hline & $\mathbf{N}$ & Min. & Max. & Mean & $\begin{array}{c}\text { Std. } \\
\text { Deviation }\end{array}$ \\
\hline $\begin{array}{c}\text { Kompensasi } \\
\text { finansial } \\
\text { (X1) }\end{array}$ & 60 & 8.00 & 15.00 & 11.6000 & 1.71928 \\
\hline $\begin{array}{c}\text { Kompensasi } \\
\text { nonfinansial } \\
\text { (X2) }\end{array}$ & 60 & 15.00 & 30.00 & 21.7833 & 2.94061 \\
\hline $\begin{array}{l}\text { Kinerja } \\
\text { karyawan } \\
\text { (Y) }\end{array}$ & 60 & 18.00 & 30.00 & 22.7333 & 2.44857 \\
\hline $\begin{array}{c}\text { Valid N } \\
\text { (listwise) }\end{array}$ & 60 & & & & \\
\hline
\end{tabular}

Sumber: data diolah

Berdasarkan statistik deskriptif, jumlah responden dalam penelitian ini adalah 60 orang karyawan. Dari 60 orang karyawan tersebut, kompensasi finansial terkecil adalah 8,00 dan kompensasi finansial terbesar adalah 15,00. Rata-rata kompensasi finansial dari 60 karyawan adalah 11,6000 dengan standar deviasi 1,71928. Kompensasi nonfinansial terkecil adalah 15,00 dan kompensasi nonfinansial terbesar adalah 30,00. Rata-rata kompensasi nonfinansial dari 60 karyawan adalah 21,7833 dengan standar deviasi sebsar 2,94061. Sedangkan untuk kinerja karyawan, dari 60 orang karyawan, kinerja karyawan terendah adalah 18,00 dan kinerja karyawan tertinggi adalah 30,00. Rata-rata kinerja karyawan adalah 22,7333 dengan standar deviasi sebesar 2,44857.

\section{Analisi Regresi Linear Berganda}

Teknik analisis data yang digunakan dalam penelitian ini adalah regresi linear berganda. Adapun persamaan regresi dalam penelitian ini adalah:

$$
\mathrm{Y}=\mathrm{b} 0+\mathrm{b} 1 \mathrm{X} 1+\mathrm{b} 2 \mathrm{X} 2 \quad \rightarrow(1)
$$


Keterangan:

$\mathrm{Y} \quad=$ kinerja karyawan

b0 = konstanta

b1 $\quad=$ koefisien regresi kompensasi finansial

$\mathrm{X} 1=$ kompensasi finansial

b2 = koefisien regresi kompensasi nonfinansial

$\mathrm{X} 2=$ kompensasi nonfinansial

Berikut ini akan disajikan hasil analisis regresi linear berganda yang terdiri dari koefisien determinasi, uji statistik F, dan uji statistik t.

\section{Koefisien Determinasi}

Untuk mengukur sejauhmana kemampuan model dalam menjelaskan variasi variabel dependen, maka digunakan koefisien determinasi. Nilai koefisien determinasi (adjusted $R$ square) disajikan pada tabel berikut.

Tabel 5. Koefisien Determinasi

\begin{tabular}{|c|c|c|c|c|}
\hline Mode & $\mathbf{R}$ & $\begin{array}{c}\mathbf{R} \\
\text { Square }\end{array}$ & $\begin{array}{l}\text { Adjusted } \\
\text { R Square }\end{array}$ & $\begin{array}{c}\text { Std. Error } \\
\text { of the } \\
\text { Estimate }\end{array}$ \\
\hline 1 & $.580^{\mathrm{a}}$ & .337 & .313 & 2.02888 \\
\hline
\end{tabular}

Berdasarkan hasil analisis regersi linear berganda tampak bahwa nilai adjusted $\mathrm{R}$ square adalah 0,313. Hal ini dapat diartikan bahwa 31,3\% variasi kinerja karyawan dapat dijelaskan oleh variasi dari dua variabel independen yaitu kompensasi finansial dan kompensasi nonfinansial, sedangkan sisanya yaitu $68,7 \%$ dijelaskan oleh variabel lain di luar model penelitian ini. Sementara itu nilai standar error of estimate (SEE) sebesar 2.02888, semakin kecil SEE maka model regresi akan semakin tepat dalam memprediksi variabel dependen.

\section{Uji Statistik F}

Uji statistik F dilakukan untuk memastikan bahwa model regresi yang digunakan dalam penelitian ini, dapat digunakan untuk memprediksi variabel dependen. Hasil uji statistik F disajikan dalam tabel berikut.

\section{Tabel 6. Hasil Uji Statistik F}

\begin{tabular}{llccccc}
\hline & Model & $\begin{array}{c}\text { Sum of } \\
\text { Square }\end{array}$ & df & $\begin{array}{c}\text { Mean } \\
\text { Square }\end{array}$ & F & Sig. \\
\hline 1 & Regression & 119.101 & 2 & 59.551 & 14.467 & $.000^{\mathrm{a}}$ \\
& Residual & 234.632 & 57 & 4.116 & & \\
& Total & 352.733 & 59 & & & \\
\hline
\end{tabular}

a. Predictors: (Constant), kompensasi nonfinansial, kompensasi finansial

b. Dependent Variable: kinerja karyawan

Sumber: data diolah
Berdasarkan uji Anova atau uji statistik F, ternyata nilai $\mathrm{F}$ hitung sebesar 14,467 dengan probalilitas sebesar 0,000 lebih kecil dari 0,05. Hal ini menunjukkan bahwa model regresi yang digunakan dalam penelitian ini dapat digunakan untuk memprediksi kinerja karyawan, atau dengan kata lain kompensasi finansial dan kompensasi nonfinansial secara bersama-sama berpengaruh terhadap kinerja karyawan.

\section{Uji Statistik t}

Uji statistik t digunakan untuk mengetahui pengaruh satu variabel independen secara individual dalam menjelaskan variasi variabel dependen. Hasil uji statistik $\mathrm{t}$ dapat dilihat pada tabel berikut.

Tabel 7. Hasil Uji Statistik t

\begin{tabular}{|c|c|c|c|c|c|c|}
\hline & \multirow[t]{2}{*}{ Model } & \multicolumn{2}{|c|}{$\begin{array}{l}\text { Unstandardized } \\
\text { Coefficients }\end{array}$} & \multirow{2}{*}{$\begin{array}{c}\begin{array}{c}\text { Standardized } \\
\text { Coefficients }\end{array} \\
\text { Beta }\end{array}$} & \multirow[t]{2}{*}{$\mathrm{t}$} & \multirow[t]{2}{*}{ Sig. } \\
\hline & & B & $\begin{array}{c}\text { Std. } \\
\text { Error }\end{array}$ & & & \\
\hline \multirow[t]{3}{*}{1} & (Constant) & 12.564 & 2.081 & & 6.036 & .000 \\
\hline & $\begin{array}{l}\text { Kompensasi } \\
\text { finansial }\end{array}$ & -.097 & .204 & -.068 & -.477 & .636 \\
\hline & $\begin{array}{l}\text { Kompensasi } \\
\text { nonfinansial }\end{array}$ & .519 & .119 & .623 & 4.355 & .000 \\
\hline
\end{tabular}

Koefisien regresi variabel independen dalam penelitian ini diinterpretasikan dengan menggunakan unstandardized beta coefficients. Berdasarkan hasil uji statistik $t$, ternyata variabel kompensasi finansial tidak signifikan, karena memiliki nilai probabilitas sebesar 0,636 (lebih besar dari 0,05), sedangkan variabel kompensasi nonfinansial signifikan, karena memiliki nilai probabilitas 0,000 (lebih kecil dari $0,05)$. Adapun persamaan regresi dalam penelitian ini adalah:

$$
\mathrm{Y}=12,564-0,097 \mathrm{X} 1+0,519 \mathrm{X} 2 \quad \rightarrow(2)
$$

Persamaan tersebut dapat diinterpretasikan sebagai berikut:

- Konstanta sebesar 12,564 dapat diartikan bahwa jika kompensasi finansial dan kompensasi nonfinansial dianggap konstan, maka kinerja karyawan sebesar 12,564.

- Koefisien regresi kompensasi finansial sebesar 0,097 artinya jika ada penambahan kompensasi finansial sebesar 1 satuan, maka akan ada penuruan kinerja karyawan sebesar 0,097.

- Koefisien regresi kompensasi nonfinansial sebesar 0,519 artinya bahwa jika ada penambahan kompensasi nonfinansial sebesar 1 satuan, maka akan ada kenaikan kinerja karyawan sebesar 0,519. 


\section{Uji Asumsi Klasik}

Sebuah model regresi akan dapat digunakan untuk memprediksi jika memenuhi beberapa asumsi yang sering disebut dengan uji asumsi klasik (Santosa, 2015). Uji asumsi klasik dalam penelitian ini terdiri dari uji multikolinieritas, uji heteroskedastisitas, dan uji normalitas.

Uji multikolinieritas bertujuan untuk menguji apakah model regresi yang digunakan terdapat korelasi antar variabel independen (Ghozali, 2016). Kriteria yang digunakan untuk uji multikolinieritas adalah dengan melihat nilai tolerance dan variance inflation factor (VIF). Jika nilai nilai tolerance lebih dari 0,10 dan VIF kurang dari 10, maka model dapat dinyatakan terbebas dari multikolinieritas. Hasil uji multikolinieritas variabel kompensasi finansial memiliki nilai tolerance sebesar 0,569 (lebih dari 0,10 ) dan VIF 1,757 (kurang dari 10). Untuk variabel kompensasi nonfinansial memiliki nilai tolerance sebesar 0,569 (lebih dari 0,10) dan VIF 1,757 (kurang dari 10). Berdasarkan hasil uji multikolinieritas maka dapat dinyatakan tidak terdapat multikolinieritas antar variabel independen dalam penelitian ini.

Uji heteroskedastisitas bertujuan untuk menguji apakah dalam model regresi yang digunakan terdapat ketidaksamaan varian dari residual satu pengamatan ke pengamatan yang lain (Ghozali, 2016). Untuk mengetahui ada tidaknya heteroskedastisitas adalah dengan melihat grafik plot antar nilai prediksi variabel dependen yaitu ZPRED dengan residualnya SRESID. Untuk mendeteksi ada tidaknya heteroskedastisitas dapat dilakukan dengan melihat ada tidaknya pola tertentu pada scatterplot antara SRESID dan ZPRED, dimana sumbu $\mathrm{Y}$ adalah $\mathrm{Y}$ yang telah diprediksi, dan sumbu $X$ adalah residual (Y prediksi - $\mathrm{Y}$ sesungguhnya) yang telah distudentized.

Dasar pengambilan keputusan adalah: (1) jika ada pola tertentu, seperti titik-titik yang ada membentuk pola tertentu yang teratur (bergelombang, melebar kemudian menyempit), maka ada indikasi terdapat heteroskedastisitas; dan (2) jika tidak ada pola jelas, dan titik-titik menyebar di atas dan di bawah angka 0 pada sumbu Y, maka tidak terdapat heteroskedastisitas (Ghozali, 2016). Hasil uji heteroskedastisitas menunjukkan bahwa titik-titik menyebar secara acak baik di atas maupun di bawah angka 0 pada sumbu Y. Hal ini menunjukkan bahwa tidak terdapat heterokedastisitas pada model regresi yang digunakan dalam penelitian ini.
Uji asumsi klasik yang terakhir adalah uji normalitas. Uji ini dilakukan untuk menguji apakah dalam model regresi, variabel pengganggu atau residual memiliki distribusi normal (Ghozali, 2016). Uji normalitas dilakukan dengan uji Kolmogorov smirnov test (KS). Hasil uji menunjukkan bahwa nilai asymp. Sig (2tailed) sebesar 0,069 lebih besar dari 0,05, maka data yang digunakan dalam penelitian ini berdistribusi normal.

\section{Pengujian Hipotesis 1}

Pengujian hipotesis dalam penelitian ini didasarkan pada nilai signifikansi. Jika nilai signifikansi lebih kecil dari 0,05 maka hipotesis didukung. Ada dua hipotesis yang akan diuji dalam penelitian ini. Pengujian hipotesis 1 adalah sebagai berikut.

- H0: kompensasi finansial tidak berpengaruh terhadap kinerja karyawan Koperasi Simpan Pinjam (KSP) Credit Union Dharma Kita Sleman.

- H1: kompensasi finansial berpengaruh terhadap kinerja karyawan Koperasi Simpan Pinjam (KSP) Credit Union Dharma Kita Sleman.

- Berdasarkan hasil uji statistik ternyata kompensasi finansial memiliki nilai signifikansi sebesar 0,636 lebih besar dari 0,05. Oleh sebab itu hipotesis 1 yang menyatakan bahwa kompensasi finansial berpengaruh terhadap kinerja karyawan Koperasi Simpan Pinjam (KSP) Credit Union Dharma Kita Sleman, tidak didukung dalam penelitian ini.

\section{Pengujian Hipotesis 2}

Hipotesis 2 yang akan diuji dalam penelitian ini adalah:

- H0: kompensasi nonfinansial tidak berpengaruh terhadap kinerja karyawan Koperasi Simpan Pinjam (KSP) Credit Union Dharma Kita Sleman.

- H2: kompensasi nonfinansial berpengaruh terhadap kinerja karyawan Koperasi Simpan Pinjam (KSP) Credit Union Dharma Kita Sleman.

- Berdasarkan hasil uji statistik t menunjukkan bahwa kompensasi nonfinansial memiliki nilai signifikansi sebesar 0,000 lebih kecil dari 0,05. Oleh sebab itu hipotesis 2 yang menyatakan bahwa kompensasi nonfinansial berpengaruh terhadap kinerja karyawan Koperasi Simpan Pinjam (KSP) Credit Union Dharma Kita Sleman, didukung dalam penelitian ini. 


\section{Pengaruh Kompensasi Finansial Terhadap Kinerja Karyawan}

Hasil penelitian ini menunjukkan bahwa kompensasi finansial tidak berpengaruh terhadap kinerja karyawan Koperasi Simpan Pinjam (KSP) Credit Union Dharma Kita Sleman. Hasil penelitian ini berbeda atau bertentangan dengan hasil penelitian yang dilakukan oleh Arief et al. (2016), Hamdan \& Setiawan (2014), Hinaya \& Suryati (2019), Ismantara \& Pranatasari (2019), Irawan et al. (2014), Leonardo \& Andreani (2015), Priyatono (2019), Suci \& Syamsir (2018), dan Syafi'ah et al. (2018), yang menemukan bahwa kompensasi finansial berpengaruh secara signifikan terhadap kinerja karyawan. Akan tetapi hasil penelitian ini mendukung penelitian yang dilakukan oleh Sulistyani \& Irawan (2018) yang menemukan bahwa kompensasi finansial tidak berpengaruh secara positif dan signifikan terhadap kinerja karyawan.

Hasil penelitian ini antara lain dapat dijelaskan dengan teori keadilan. Menurut teori keadilan, karyawan akan mengevaluasi gaji mereka secara relatif terhadap gaji orang lain. Orang akan membandingkan rasio hasil yang dipersepsikan dalam hal ini gaji, bonus, dan tunjangan kesehatan, terhadap input yang dipersepsikan yaitu usaha, tingkat pendidikan, dan masa kerja dengan rasio perbandingan orang lain. Jika rasio hasil dan input yang dipersepsikan lebih kecil daripada rasio perbandingan orang lain, maka muncul persepsi ketidakadilan (Noe et al., 2011).

Ada beberapa dimensi yang perlu dipertimbangkan terkait dengan keadilan kompensasi, yaitu keadilan internal, keadilan eksternal, dan keadilan individual (Al Fajar \& Heru, 2013). Keadilan internal artinya besarnya kompensasi dikaitkan dengan nilai relatif dari pekerjaan dan pembayaran karyawan yang satu dibandingkan dengan pembayaran karyawan yang lain dalam organisasi yang sama. Pekerjaan yang beban kerja dan tanggungjawab lebih besar, seharusnya dibayar lebih besar daripada pekerjaan dengan beban kerja dan tanggungjawab yang lebih rendah (Hanggraeni, 2012). Keadilan eksternal artinya pembayaran yang diberikan kepada karyawan layak atau sama dengan yang diterima oleh para karyawan yang serupa di organisasi lain. Sedangkan keadilan individual berkaitan dengan perbandingan antara rasio output dengan input mereka yang diberikan kepada organisasi.

Sesuai dengan hasil penelitian ini, maka diduga karyawan Koperasi Simpan Pinjam (KSP) Credit
Union Dharma Kita Sleman, memiliki persepsi ketidakadilan terhadap kompensasi finansial yang mereka terima. Akibatnya mereka mengurangi inputnya atau usahanya dengan tidak bekerja keras, yang pada gilirannya kinerja mereka menurun.

Berdasarkan teori keadilan ini, maka ada kemungkinan bahwa hubungan antara kompensasi finansial dengan kinerja karyawan dimediasi oleh kepuasan dan motivasi. Karyawan yang menerima kompensasi finansial secara adil, akan merasa puas, sebaliknya karyawan yang menerima kompensasi finansial secara tidak adil, merasa tidak puas. Karyawan yang merasa puas, selanjutnya akan termotivasi untuk bekerja lebih keras lagi, yang pada gilirannya akan meningkatkan kinerja mereka. Sebaliknya karyawan yang tidak puas, tidak termotivasi untuk bekerja lebih keras, mereka justru akan mengurangi usahanya, yang selanjutnya akan berdampak pada penurunan kinerja.

\section{Pengaruh Kompensasi Nonfinansial Terhadap Kinerja Karyawan}

Hasil penelitian ini menunjukkan bahwa kompensasi nonfinansial berpengaruh terhadap kinerja karyawan koperasi karyawan Koperasi Simpan Pinjam (KSP) Credit Union Dharma Kita Sleman. Hasil penelitian ini mendukung hasil penelitian yang dilakukan oleh Hadi (2014), Hamdan \& Setiawan (2014), Hinaya \& Suryati (2019), Ismantara \& Pranatasari (2019), Leonardo \& Andreani (2015), Priyatono (2019), Suseno et al. (2014), dan Syafi'ah et al. (2018), yang menemukan bahwa kompensasi nonfinansial berpengaruh secara signifikan terhadap kinerja karyawan.

Menurut Armstrong \& Taylor (2014) sistem kompensasi merupakan komponen-komponen yang saling terkait, yang dapat mempengaruhi kinerja karyawan. Sistem kompensasi didasarkan pada strategi bisnis, yang selanjutnya sebagai dasar dalam penyusunan strategi kompensasi. Kompensasi total terdiri dua komponen utama yaitu kompensasi finansial dan kompensasi nonfinansial. Manajemen kinerja memiliki peran penting dalam mendukung kompensasi nonfinansial dan dapat digunakan untuk menginformasikan kinerja atau keputusan pembayaran kontribusi. Semua komponen ini bergabung untuk mempengaruhi tingkat kinerja.

\section{SIMPULAN DAN SARAN}

Berdasarkan hasil penelitian ini, maka dapat disimpulkan bahwa: (1) kompensasi finansial tidak berpengaruh terhadap kinerja karyawan Koperasi Simpan Pinjam Credit Union Dharma Kita Sleman; dan (2) kompensasi nonfinansial berpengaruh 
terhadap kinerja karyawan Koperasi Simpan Pinjam Credit Union Dharma Kita Sleman, Yogyakarta.

Penelitian ini memiliki beberapa keterbatasan antara lain, pertama, subjek dalam penelitian ini terbatas hanya karyawan Koperasi Simpan Pinjam Credit Union Dharma Kita Sleman, Yogyakarta. Untuk penelitian selanjutnya sebaiknya menggunakan subjek atau responden yang berbeda, pada organisasi koperasi yang berbeda, dan di area atau daerah yang berbeda pula. Kedua, variabel prediktor yang digunakan dalam penelitian terbatas yaitu hanya variabel kompensasi finansial dan kompensasi nonfinansial. Untuk penelitian selanjutnya sebaiknya menggunakan variabel lain yang diduga menjadi prediktor kinerja karyawan, seperti kemampuan dan keterampilan, motivasi, dukungan rekan kerja dan sebagainya.

\section{DAFTAR PUSTAKA}

Al Fajar, S., \& Heru, T. (2013). Manajemen Sumber Daya Manusia Sebagai Dasar Meraih Keunggulan Bersaing. UPP STIM YKPN.

Arief, M. Y., Harisandi, Y., \& Nugraheni, G. (2016). Pengaruh Kompensasi Finansial Dan Non Finansial Terhadap Kinerja Karyawan Bagian Instalasi Pada Ptpn Xi (persero) Pg Pradjekan Bondowoso. Jurnal Ekonomi Dan Bisnis Growth, 14(1), 59-78.

Arikunto, S. (2010). Prosedur Penelitian Suatu Pendekatan Praktik. Rineka Cipta.

Armstrong, M., \& Taylor, S. (2014). A Handbook of Human Resource Management Practice. Kogan Page Publishers.

Creswell, J. W. (2014). Research Design Pendekatan Kualitatif, Kuantitatif, Dan Mixed (3rd ed.). Pustaka Pelajar.

Ghozali, I. (2016). Aplikasi Analisis Multivariete Dengan Program Ibm Spss 23 (8th ed.). Badan Penerbit Universitas Diponegoro.

Hadi, L. (2014). Pengaruh Kompensasi Finansial Dan Non Finansial Terhadap Kinerja Karyawan Bumn ( Studi Kasus Pt. Bank Rakyat Indonesia (persero) Tbk. Cabang Teluk Kuantan). Jurnal Al-Iqtishad, 2, 50-72.

Hamdan, E., \& Setiawan, R. (2014). Pengaruh Kompensasi Finansial Dan Non Finansial Terhadap Kinerja Karyawan Pt. Samudera Buana Persada. Agora, 2(1).
Handayani, S. (2017). Pengaruh Kompensasi Finansial Terhadap Kinerja Pegawai Harian Lepas Di Dinas Lingkungan Hidup Dan Kebersihan Kota Palembang. Jurnal Ilmiah Ekonomi Global Masa Kini, 8(1), 12-20.

Hanggraeni, D. (2012). Manajemen Sumber Daya Manusia. Lembaga Penerbit Fakultas Ekonomi Universitas Indonesia.

Hinaya, \& Suryati. (2019). Pengaruh Kompensasi Finansial Dan Nonfinansial Terhadap Kinerja Karyawan Pada Kantor Badan Penanggulangan Bencana Daerah (bpbd) Kota Palopo. Jurnal Mirai Management, 4(1), 273-295.

Irawan, D. H., Hamid, D., \& Riza, M. F. (2014). Pengaruh Kompensasi Finansial Dan Kompensasi Non Finansial Terhadap Kinerja (studi Pada Agen Ajb Bumiputera 1912 Kantor Cabang Blitar). Jurnal Administrasi Bisnis, 13(1), 1-9.

Ismantara, W. R., \& Pranatasari, F. D. (2019). Pengaruh Kompensasi Finansial Dan Kompensasi Nonfinansial Terhadap Tenaga Kerja Perusahaan (studi Pada Spbu Bs Group). Business Management Journal, 15(1), 63-72.

Leonardo, E., \& Andreani, F. (2015). Pengaruh Pemberian Kompensasi Terhadap Kinerja Karyawan Pada Pt. Kopanitia. Agora, 3(2), 28-31.

Mangkunegara, A. P. (2017). Manajemen Sumber Daya Manusia Perusahaan. Remaja Rosdakarya.

Mustafa, Z. (2013). Mengurai Variabel Hingga Instrumen. Graha ilmu.

Noe, R. A., R. Hollenbeck, J., Gerhart, B., \& Wright, P. (2011). Manajemen Sumber Daya Manusia Mencapai Keunggulan Bersaing (6th ed.). Salemba Empat.

Priyatono, M. (2019). Pengaruh Kompensasi Finansial Dan Non Finansial Terhadap Kinerja Karyawan Mesastila Hotels Dan Resorts. Media Wisata, 17(1), 56-59.

Santosa, S. (2015). Mengasai Statistik Parametrik Konsep Dan Aplikasi Dengan Spss. Elex Media Komputindo.

Sinambela, L. P. (2016). Manajemen Sumber Daya Manusia. Bumi Aksara.

Suci, R., \& Syamsir. (2018). Pengaruh Kompensasi Terhadap Kinerja Perangkat Nagari Dalam Pengelolaan Keuangan Nagari Di Kecamatan Salimpaung. Journal of Education on Social Science, 2(1), 47-58. 
Sulistyani, H., \& Irawan, B. (2018). "Pengaruh Kompensasi Finansial Terhadap Kinerja Pegawai Di Direktorat Serealia Direktorat Jenderal Tanaman Pangan Kementerian Pertanian. Reformasi Administrasi Jurnal Ilmiah Untuk Mewujudkan Masyarakat Madani, 5(1), 20-26.

Suseno, E. S., Hamid, D., \& Ruhana, I. (2014). Pengaruh Kompensasi Finansial Dan Non Finansial Terhadap Kinerja Karyawan (studi Pada Bank Rakyat Indonesia Cabang Jember). Jurnal Administrasi Bisnis, 8(2), 1-6.

Syafi'ah, N., Djaelani, A. K., \& Anwarudin B.S, M. K. (2018). Pengaruh Kompensasi Finansial Dan Non Finansial Terhadap Prestasi Kerja Karyawan (studi Pada Pt. Polowijo Gosari Gresik). E-Jurnal Riset Manajemen, 7(2), 26-36.

Wibowo. (2016). Manajemen Kinerja (5th ed.). RajaGrafindo Persada.

Wirawan. (2009). Evaluasi Kinerja Sumber Daya Manusia Teori, Aplikasi, Dan Penelitian. Salemba Empat.

Yuniarsih, T., \& Suwatno. (2016). Manajemen Sumber Daya Manusia. Alfabeta. 
300 Coopetition, Vol XII, Nomor 2, Juli 2021,

(E-ISSN : 2615-4978, P-ISSN : 2086-4620) 